LiNb 結晶上の表面弹性波によるX線回折強度の变化

\title{
(東大.工) -中谷信一郎，高椅领男，菊田显志
}

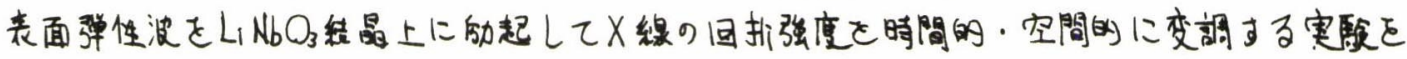

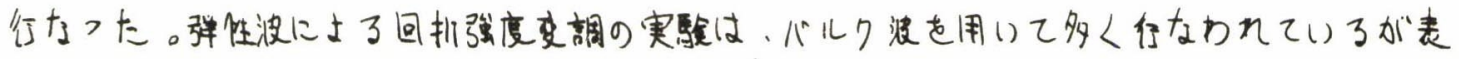

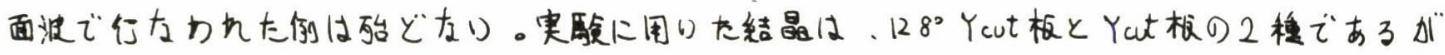

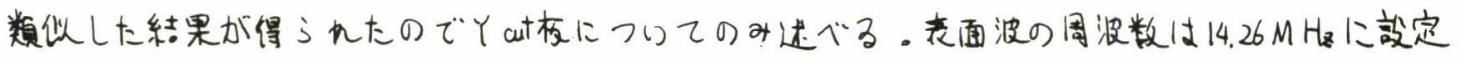

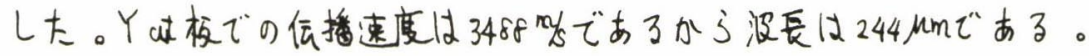

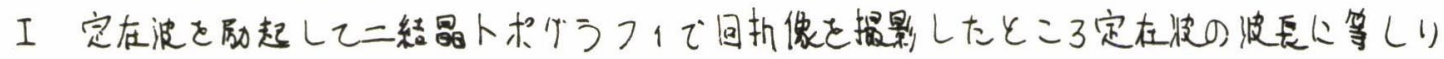

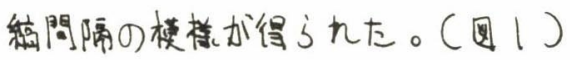

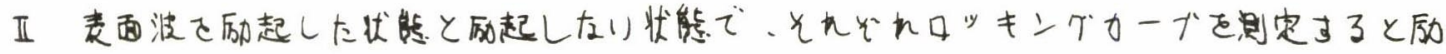

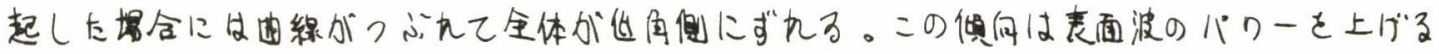

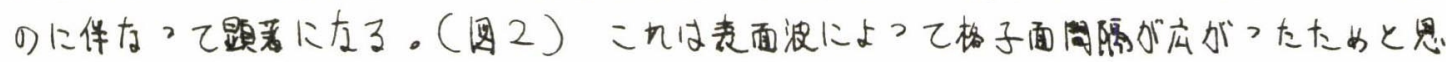
われる。

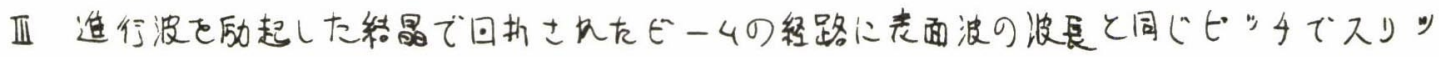

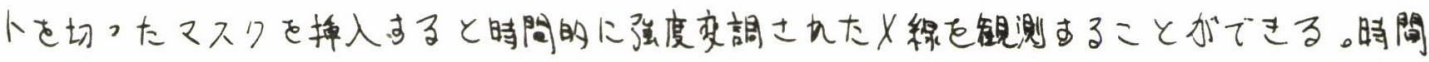

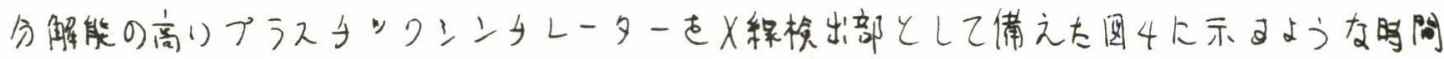

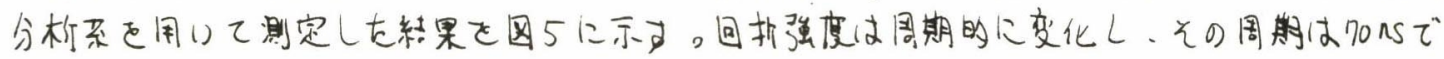
表面波の周期に一致してりる。この結

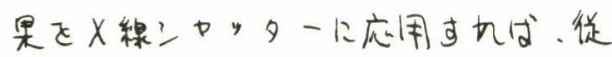
来のものに比べはるかに高速で钩作す るシャ”夕一が实现子可能性がある。国、 結晶已提供して预した日本電気(株) の西川腾㢁，浅川潔の两氏にお礼を申 し上げます。
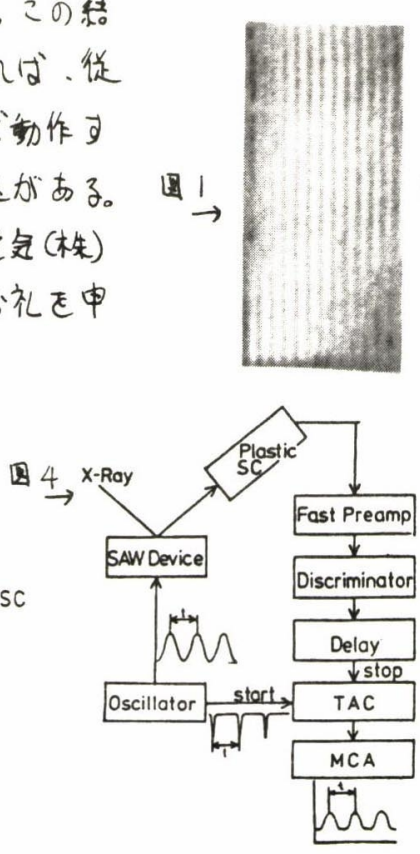

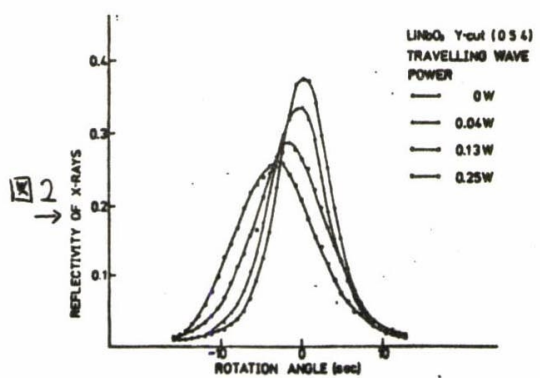

图 5

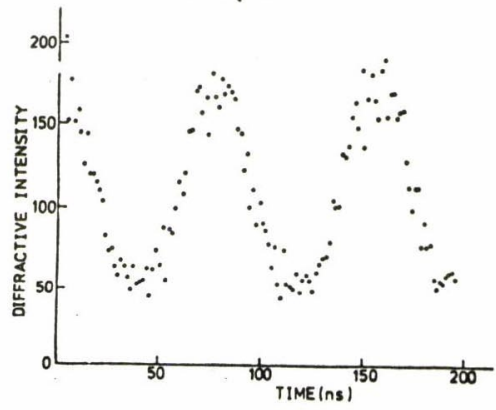

